\title{
Management of Gallbladder Polyps: A Tertiary Center Experience
}

\author{
Safra Kesesi Poliplerinin Yönetimi: \\ Bir Üçüncü Basamak Deneyimi
}

\section{Özgün Araştırma Research Article}

\author{
Mehmet Üstün®, Avni Can Karaca $\odot$, Cengiz Aydın®
}

\section{ABSTRACT}

Objective: The main purpose of the management of gallbladder polyps is to establish an early diagnosis and to prevent the development of gallbladder cancer.

Methods: Fifty-six patients who underwent cholecystectomy with the diagnosis of gallbladder polyp between January 2012 and September 2018, were retrospectively evaluated.

Results: Twenty-one patients (39.3\%) were female and 34 (60.7\%) were male. The indications for cholecystectomy were $\geq 10 \mathrm{~mm}$ polyps in ( $n=22,39.3 \%)$, increase in polyp size during follow-up $(n=8,14.3 \%)$, symptomatic polyps smaller than $10 \mathrm{~mm}(n=24,42.9 \%)$, polyps smaller than $10 \mathrm{~mm}$ with concomitant risk factors $(n=2,3.6 \%)$. Histopathological examination of gallbladders revealed the presence of cholesterol polyps in 51 (91.1\%), inflammatory polyps in $1(1.8 \%)$, and adenoma in $1(1.8 \%)$ patient. Three patients (5.4\%) had no polyps and only gallstones were detected. Malignancy was not detected in any patient.

Conclusion: The management of gallbladder polyps is still a controversial issue. The recommendations published in guidelines, can be used as a guide in the management of gallbladder polyps. The characteristics of symptoms and their response to cholecystectomy should be evaluated in symptomatic cases.

Keywords: Gallbladder polyp, cholecystectomy, gallbladder cancer

Öz

Amaç: Safra kesesi poliplerinin yönetiminde temel amaç safra kesesi kanseri gelişiminin önüne geçmek ya da erken tanı koymaktır.

Yöntem: Ocak 2012 - Eylül 2018 tarihleri arasında safra kesesi polibi tanısıyla kolesistektomi uygulanan 56 hasta retrospektif olarak değerlendirildi.

Bulgular: Hastaların 22'si erkek (\%39,3), 34'ü kadındı (\%60,7). Hastaların 22'si (\%39,3) $10 \mathrm{~mm}$ ve üzeri polip boyutu, 8'i (\%14,3) takipte boyut artışı, 24'ü (\%42,9) 10 mm'den küçük polip boyutu ancak semptomatik, 2'si $(\% 3,6) 10$ mm'den küçük ancak beraberinde risk faktörleri olması endikasyonları ile opere edildi. Elli bir hastada (\%91,1) kolesterol polibi, 1 hastada $(\% 1,8)$ inflamatuvar polip, 1 hastada $(\% 1,8)$ adenom saptandı. Hastalardan 3'ünde $(\% 5,4)$ safra kesesi histopatolojik incelemesinde polibe rastlanmamış olup, yalnızca taş saptanmıştır. Hiçbir hastada malignite saptanmamıştır.

Sonuç: Safra kesesi poliplerinin tedavi ve yönetimi halen tartışmalı bir konudur. Yayınlanan kılavuzlardaki öneriler, safra kesesi polip yönetiminde rehber olarak kullanılabilir. Semptomatik olgularda semptomlarn karakteristiği ve kolesistektomiye yanıtı iyi değerlendirilmelidir.

Anahtar kelimeler: Safra kesesi polibi, kolesistektomi, safra kesesi kanseri
SBÜ Tepecik Eğitim ve Araștırma Hastanesi Genel Cerrahi Kliniği Izmir - Türkiye dr.m.ustun@gmail.com ORCID: 0000-0003-2646-5239

A.C. Karaca 0000-0003-4930-6222 İmir Ekonomi Üniversitesi Tıp Fakültesi, Genel Cerrahi Ana Bilim Dali, izmir, Türkiye

C. Aydın 0000-0003-4713-2871 SBÜ Tepecik Eğitim ve Araştırma Hastanesi, Genel Cerrahi Kliniği, Izmir, Türkiye

Cite as: Üstün M, Karaca AC, Aydin C. Management of gallbladder polyps: A tertiary center experience. Tepecik Eğit. ve Araşt. Hast. Dergisi. $2019 ; 29(2): 129-33$ (c) Telif hakkı T.C. Sağık Bakanlığı İmir Tepecik Eğit. ve Araşt. Hastanesi. Logos Tıp Yayıncılık tarafindan yayınlanmaktadır. Bu dergide yayınlanan bütün makaleler Creative Commons Attf-GayriTicari 4.0 Uluslararası Lisansı ile lisanslanmıştır.

(c) Copyright Association of Publication of the T.C. Ministry of Health Izmir Tepecik Education and Research Hospital. This journal published by Logos Medical Publishing. Licenced by Creative Commons Attribution-NonCommercial 4.0 International (CC BY-NC 4.0) 


\section{INTRODUCTION}

The incidence of gallbladder polyps (GPs) in healthy individuals is between $0.3-12 \%{ }^{(1)}$. They are classified into two groups as true polyps and pseudopolyps. Pseudopolyps are more common (70\%) than true polyps ${ }^{(2)}$. Pseudopolyps consists of cholesterol polyps, focal adenomyosis, hyperplastic polyps and inflammatory polyps, however true polyps are either adenomas or adenocarcinomas. Pseudopolyps do not have malignant potential and follow-up is not required. On the contrary, the adenomas bear malignant potential and they need to be surgically removed ${ }^{(3)}$.

The main purpose of the management of gallbladder polyps is to establish an early diagnosis and to prevent the development of gallbladder cancer. Gallbladder cancer has poor prognosis, with the only option for treatment is early diagnosis and curative surgery ${ }^{(4)}$. Therefore, management of gallbladder polyps is very important.

The aim of this study is to evaluate the data from patients who underwent cholecystectomy with the diagnosis of GP together with a brief review of the available literature.

\section{MATERIAL and METHOD}

Data from 56 patients who underwent cholecystectomy with the diagnosis of gallbladder polyps between January 2012 and September 2018, were retrospectively evaluated. Abdominal ultrasonography of all patients was performed in our hospital by an experienced radiologist.

The indications of cholecystectomy were as follows: presence of a $\geq 10 \mathrm{~mm}$ polyp, or $<10 \mathrm{~mm}$ polyps causing biliary symptoms (right upper quadrant pain, nausea, vomiting and rarely bloating after meals) or having risk factors (age over 50 years and single or sessile polyp), and polyps increasing in size on follow-up.
The demographics, ASA (American Society of Anesthesiologists) scores, the number and size of polyps in the ultrasonography (the largest polyp among multiple polyps), concomitant gallstones, pathology results, perioperative and postoperative complications and length of stay were recorded and retrospectively analyzed.

Descriptive statistics and freqeuencies were analyzed using Statistical Package for the Social Sciences (SPSS) version 25 by International Business Machines Corporation (IBM), New York, United States.

The approval was obtained from the ethical committee of our hospital dated 27.12.2018 and decision number 18/16-4.

\section{RESULTS}

The data from 56 patients who underwent cholecystectomy with the diagnosis of GP were retrospectively analyzed. All demographics and clinical data of the patients are summarized in Table 1.

Twenty-one patients (39.3\%) were female and 34 $(60.7 \%)$ were male. The mean age was 43.2 (SD:

Table 1. Demographic and clinical datas.

\begin{tabular}{lc}
\hline Characteristics & $\mathrm{n}$ \\
\hline Male/Female & $22 / 34$ \\
& $(39.3 \%-60.7 \%)$ \\
Age (mean (range)) & $43.2(18-72)$ \\
Operated because of $10 \mathrm{~mm}$ and greater polyp size & $22(39.3 \%)$ \\
Operated because of increased polyp size & $8(14.3 \%)$ \\
$\begin{array}{l}\text { Operated because of polyps less than } 10 \mathrm{~mm}+\text { risk } \\
\text { factors }\end{array}$ & $2(3.6 \%)$ \\
$\begin{array}{l}\text { Operated because of polyps less than } 10 \mathrm{~mm}+ \\
\text { symptoms }\end{array}$ & $24(42.9 \%)$ \\
No gallstone in USG and pathological examination & $44(78.6 \%)$ \\
Gallstone in pathological examination but not in USG & $8(14.3 \%)$ \\
Gallstone in USG and pathological examination & $4(7.1 \%)$ \\
\hline
\end{tabular}


11.952, range 18-72) years. Mean preoperative ASA score was 1.86 (SD: 0.444).

The most common indication for cholecystectomy was symptomatic polyps with less than $10 \mathrm{~mm}$ in size which was diagnosed in 24 (42.9\%) patients. Twentytwo patients had polyps greater than $10 \mathrm{~mm}$ (39.3\%). Eight (14.3\%) patients were operated due to increase in polyp size during follow-up. Two patients (3.6\%) were operated due to risk factors associated with polyps less than $10 \mathrm{~mm}$. Both patients were over 50 years old and they have sessile polyps.

Thirty-five (62.5\%) patients had single and 21 (37.5\%) multiple polyps. Gallstones were not detected in both ultrasonography and pathological examination of gall bladder in 44 (78.6\%) patients. Four (7.1\%) patients had gallstones detected in both ultrasonography and pathological examinations, whereas 8 (14.3\%) patients had gallstones detected only in pathological examination. In 3 of these patients (5.4\%), no polyp was found in histopathological examination of the gallbladder.

Laparoscopic intervention was performed in all patients and cholecystectomy was performed laparoscopically in 55 patients. Conversion to open cholecystectomy was necessary in only one patient, due to inability to control perioperative bleeding The mean length of hospitalization during the postoperative period was 1.55 days (SD: 1.043). All of the patients ( $n=55,98.2 \%$ ) except one were discharged without any complication in the postoperative period. This patient had biliary fistula developed during postoperative period. In endoscopic retrograde cho-

Table 2. Histopathological results.

\begin{tabular}{lc}
\hline Histopathological results & $\mathbf{n}$ \\
\hline Cholesterol polyps & $51(91.1 \%)$ \\
Gallstone without polyps & $3(5.4 \%)$ \\
Inflammatory polyp & $1(1.8 \%)$ \\
Adenoma & $1(1.8 \%)$
\end{tabular}

langiopancreatography (ERCP) cystic stump and main biliary tract were proven normal and a sphincterotomy was performed. The drainage from the fistula stopped on the postoperative $7^{\text {th }}$ day and the patient was discharged on the $8^{\text {th }}$ postoperative day.

Histopathological examination of the gallbladder revealed the presence of cholesterol polyps in 51 (91.1\%), inflammatory polyps in $1(1.8 \%)$, and 1 adenoma in 1 (1.8\%) patient. Three patients (5.4\%) had not any polyps and only gallstones were detected. Malignancy was not detected in any patient (Table 2).

\section{DISCUSSION}

The incidence of GP varies according to geographical regions and ethnic groups and most commonly seen in Asian societies. Mean age is $45-49$ years and there is no difference between the genders ${ }^{(5)}$. Gender and age profile of this study is similar to the current literature. GP is usually asymptomatic and is detected incidentally during radiological examinations performed for other reasons ${ }^{(6)}$. However, biliary colic symptoms may be present due to intermittent obstructions caused by small cholesterol fragments detached from the wall of the gallbladder. In rare cases, acute cholecystitis or obstructive jaundice may be seen due to obstruction of the cystic duct or common biliary duct ${ }^{(3)}$. Abdominal ultrasonography is the gold standard in the diagnosis and follow-up of GP ${ }^{(5)}$.

In this study; all patients were diagnosed with abdominal ultrasonography and the most $(42.9 \%)$ of them were operated due to biliary symptoms and they have polyps with less than $10 \mathrm{~mm}$ in size. None of them have acute cholecystitis or obstructive jaundice. Although GP is usually asymptomatic, most of the patients in this study were operated due to biliary symptoms and they have polyps with less than $10 \mathrm{~mm}$ in size. The reason of this may be insufficient evaluation of the symptoms. It should be noted that 
similar symptoms may be due to other gastrointestinal pathologies. If cholecystectomy is planned with this indication, symptoms should be evaluated well and biliary symptoms should be identified. No data could be found about the response to the symptoms of these patients after cholecystectomy.

The main risk factor for malignancy in GP is polyp size. If the polyp size is $10 \mathrm{~mm}$ or greater they are considered suspicious for malignancy ${ }^{(5)}$. Bhatt et al. (7) reported that $84.7 \%$ of malignant polyps were above $10 \mathrm{~mm}$ in a review article studying the risk factors for malignancy. However, the risk of malignancy in polyps less than $4-5 \mathrm{~mm}$ is almost zero ${ }^{(5)}$.

Other risk factors for malignancy with less evidence level are single polyps, polyps associated with gallstone and gastrointestinal polyposis syndrome ${ }^{(5,12)}$.

There is no consensus about treatment and management of GP. There are different treatment approaches and management algorithms. Recently, European Society of Gastrointestinal and Abdominal Radiology (ESGAR), European Association for Endoscopic Surgery and other Interventional Techniques (EAES), International Society of Digestive Surgery-European Federation (EFISDS) and European Society of Gastrointestinal Endoscopy (ESGE) published a guideline which we think that it will help to create consensus on GP management ${ }^{(13)}$. According to this guideline; cholecystectomy is recommended for the patients with polyp size $10 \mathrm{~mm}$ and greater, for symptomatic $<10 \mathrm{~mm}$ polyps (biliary symptoms) and for the patients with 6-9 mm polyps associated with risk factors ( 50 years and older, sessile polyp, Primary Sclerosing Cholangitis (PSC) history, Indian ethnic origin) with polyps measuring between 6-9 $\mathrm{mm}$. Follow up with ultrasonography every 6 months in the first year and once a year in the subsequent 5 years is recommended for the patients without risk factors and with polyps less than $10 \mathrm{~mm}$ in size and for the patients with $<5 \mathrm{~mm}$ polyps associated with risk factors. For the cases with polyps measuring 5 $\mathrm{mm}$ and less and without risk factors, 1-, 3- and 5year- follow-ups with ultrasonography is recommended.

According to the guideline, cholecystectomy is recommended for all patients with polyps measuring 10 $\mathrm{mm}$ or $\geq 2 \mathrm{~mm}$ increase in polyps detected during follow-up. If the polyp disappears during follow-up, the follow up can be discontinued.

Similarly, in a review published in 2017 by Vila et al. (5) cholecystectomy is recommended for patients aged $\geq 50$ years with $6-9 \mathrm{~mm}$ single or sessile polyps.

The indications for cholecystectomy in this study are similar to those suggestions in the literature. In the histopathological examinations of the gallbladder, no malignancy was found in any of the patients and only 1 patient had a true polyp as adenoma. Similar to literature most of them were cholesterol polyps. However, the relatively low number of detected true polyps can be explained by the small number in our case series.

As a conclusion; when the gallbladder cancer is not diagnosed early, its prognosis is rather poor, so the management of GP is very important. However, there is still no consensus on its management. The recommendations published in guidelines, can be used as a guide in the management of gallbladder polyps.

If cholecystectomy is planned for patients with polyp size less than $10 \mathrm{~mm}$ for symptoms, the characteristic of symptoms and the response of cholecystectomy to the symptoms should be evaluated well.

The limitations of this study may be the small number in our series and deficiency in the evaluation of responses to symptoms. 
Ethics Committee Approval: The approval was obtained from the ethical committee of our hospital dated 27.12.2018 and decision number 18/16-4.

Conflict of Interest: They do not have any conflict of interest.

Funding: The authors of this manuscript did not receive any funding for the preparation of this manuscript.

Informed Consent:

Etik Kurul Onayı: Onay, hastanemiz etik kurulundan 27.12.2018 tarihli ve 18 / 16-4 sayılı karardan alınmıştır.

Çıkar Çatışması: Herhangi bir çıkar çatışması yoktur.

Finansal Destek: Bu yazının yazarları bu yazının hazırlanması için herhangi bir fon almamıştır.

\section{Hasta Onamı:}

\section{REFERENCES}

1. Cha $\mathrm{BH}, \mathrm{Hwang} \mathrm{JH}$, Lee $\mathrm{SH}$ et al. Pre-operative factors that can predict neoplastic polypoid lesions of the gallbladder. World J Gastroenterol. 2011;17(17):2216-22. [CrossRef]

2. Elmasry M, Lindop D, Dunne DF, Malik H, Poston GJ, Fenwick
SW. The risk of malignancy in ultrasound detected gallbladder polyps: a systematic review. Int J Surg. 2016;33:28-35. [CrossRef]

3. Andrén-Sandberg A. Diagnosis and management of gallbladder polyps. N Am J Med Sci. 2012;4(5):203-11. [CrossRef]

4. Park JK, Yoon YB, Kim YT et al. Management strategies for gallbladder polyps: is it possible to predict malignant gallbladder polyps? Gut Liver. 2008;2(2):88-94. [CrossRef]

5. Vila M, Lladó L, Ramos E. Management and treatment of gallbladder polyps. Med Clin (Barc). 2018;150(12):487-91. [CrossRef]

6. Lee SR, Kim HO, Shin JH. Reasonable cholecystectomy of gallbladder polyp - 10 years of experience. Asian J Surg. 2019;42(1):332-37. [CrossRef]

7. Bhatt NR, Gillis A, Smoothey CO, Awan FN, Ridgway PF. Evidence based management of polyps of the gall bladder: $A$ systematic review of the risk factors of malignancy. Surgeon. 2016;14(5):278-86. [CrossRef]

8. Mori $\mathrm{Y}$, Sato N, Matayoshi N et al. Rare combination of familial adenomatous polyposis and gallbladder polyps. World J Gastroenterol. 2014;20(46):17661-5. [CrossRef]

9. Wiles R, Thoeni RF, Barbu ST et al. Management and followup of gallbladder polyps: Joint guidelines between the European Society of Gastrointestinal and Abdominal Radiology (ESGAR), European Association for Endoscopic Surgery and other Interventional Techniques (EAES), International Society of Digestive Surgery-European Federation (EFISDS) and European Society of Gastrointestinal Endoscopy (ESGE). Eur Radiol. 2017;27(9):3856-66. [CrossRef] 